\title{
Print media as a migrant advocacy tool: A case of Indonesian language print media in Hong Kong
}

\author{
Media cetak sebagai alat advokasi migran: Kasus media cetak bahasa \\ Indonesia di Hong Kong
}

\author{
Irfan Wahyudi ${ }^{1}$ \& Panizza Allmark ${ }^{2}$ \\ ${ }^{1}$ Department of Communication, Faculty of Social and Political Sciences, Universitas Airlangga \\ ${ }^{2}$ School of Arts and Humanities, Edith Cowan University \\ Address: ${ }^{1}$ Jalan Dharmawangsa Dalam, Surabaya, East Java 60286 \\ ${ }^{2} 270$ Joondalup Dr, Joondalup Western Australia 6027, Australia \\ E-mail: irfan.wahyudi@fisip.unair.ac.id
}

\begin{abstract}
Hong Kong is listed as one of the most popular countries for Indonesian migrant workers. In 2012, more than 160,000 Indonesian migrant domestic workers (IMDWs) live in Hong Kong, and more than 90\% of them are women. Hong Kong is the premium destination for IMDWs because of its moderately higher salaries, good laws and regulations, and its ambience of independence. The IMDWs can also access multiple media platforms, ranging from print media to the Internet. This writing specifically discuss about Indonesian newspaper published in Hong Kong and its relation with migrant activism. The research found that there are four existing Indonesian language newspapers in Hong Kong: Suara, Apa Kabar Plus, Koran Indonesia (KINDO), and Berita Indonesia. Conflicts between newspaper journalists and migrant organizations have affected the newspapers' credibility. The methodology used is ethnography. Fieldwork conducted in Hong Kong Special Administrative Region (SAR) in 2013, 2014 and 2018. Participant observations, in-depth interviews, and focus group discussions were conducted in this research. Despite pros and cons regarding the existence of Indonesian print media in Hong Kong, they have undeniably contributed to the capacity development of IMDWs in Hong Kong. Print media have published a variety of news useful for IMDWs, fulfilling their need not only for information, but also for entertainment. Different positions taken by the newspapers provide choices for IMDWs in accessing relevant information for their needs. The activities performed by journalists have also enriched the IMDWs' experience and access to the knowledge that they need outside of their isolated workplaces. The Indonesian print media provides access for IMDWs to news about their surroundings. The newspapers and magazines function not only as a bridge of information to what is happening in Hong Kong, but they also continually inform the IMDW community. This provides genuine evidence of how a diasporic community can communicate through various channels and utilise those channels to strengthen bonds among the migrants.
\end{abstract}

Keywords: newspaper; community; migrant; activism; ethnography

Abstrak
Hongkong merupakan salah satu negara yang paling populer di kalangan pekerja migran di Indonesia. Pada
tahun 2012, lebih dari 160.000 pekerja migran domestik dari Indonesia (PMDI) tinggal di Hongkong, dan
lebih dari 90\% dari mereka adalah perempuan. Hongkong merupakan destinasi premium bagi para PMDI
karena memiliki rata-rata gaji yang tinggi, sistem hukum dan regulasi yang baik, dan lingkungan yang penuh
kebebasan. Para PMDI juga dapat mengakses berbagai platform media, mulai dari media cetak hingga
internet. Penelitian ini membahas khususnya mengenai surat kabar Indonesia yang diterbitkan di Hongkong
and hubungannya dengan para aktifis migran. Penelitian menemukan bahwa terdapat empat empat surat
kabar berbahasa Indonesia di Hong Kong. Suara, Apa Kabar Plus, Koran Indonesia (KINDO), dan Berita
Indonesia. Konflikyang terjadi antara jurnalis surat kabar and organisasi buruh migran telah memepengaruhi
kredibilitas surat kabar tersebut. Metodologi yang digunakan adalah etnografi. Studi lapangan dilakukan di
Wilayah Administratif Khusus (WAK) di Hong Kong pada tahun 2013, 2014 dan 2018. Dalam penelitian ini
dilakukan observasi pada para participan, wawancara mendalam, dan diskusi kelompok terarah. Terlepas
dari pro dan kontra mengenai keberadaan media cetak Indonesia di Hong Kong, mereka tidak dapat
disangkal berkontribusi pada pengembangan kapasitas IMDWs di Hong Kong. Media cetak telah menerbitkan
berbagai berita yang berguna untuk IMDW, memenuhi kebutuhan mereka tidak hanya untuk informasi, tetapi
juga untuk hiburan. Posisi berbeda yang diambil oleh surat kabar memberikan pilihan bagi IMDW dalam
mengakses informasi yang relevan untuk kebutuhan mereka. Kegiatan yang dilakukan oleh wartawan juga
telah memperkaya pengalaman IMDW dan akses ke pengetahuan yang mereka butuhkan di luar tempat kerja


mereka yang terisolasi. Media cetak Indonesia menyediakan akses untuk IMDW ke berita tentang lingkungan mereka. Koran dan majalah berfungsi tidak hanya sebagai jembatan informasi untuk apa yang terjadi di Hong Kong, tetapi mereka juga terus menginformasikan komunitas IMDW. Ini memberikan bukti nyata bagaimana komunitas diaspora dapat berkomunikasi melalui berbagai saluran dan memanfaatkan saluran tersebut untuk memperkuat ikatan di antara para migran.

Kata kunci: surat kabar; komunitas; migrant; aktivis; etnografi

\section{Introduction}

Indonesian Migrant Domestic Workers (IMDWs) in Hong Kong are fortunate to have access to a range of resources that allow them to stay up to date with the latest information, such as the establishment of Indonesian free newspapers. There are more than 150,000 IMDWs in Hong Kong and their existence encourages commercial and independent publishers to produce free newspapers in Indonesian. These Indonesian free newspapers are produced and printed in Hong Kong, and generally publish news about IMDW-related issues.

The Indonesian free newspapers in Hong Kong profit from selling advertising space. Several publications are supported by companies that use them as the main media to promote their products. The Indonesian free newspapers allows migrant workers to freely access news written in their own language so then they can digest the information easily. This writing aims to examine the Indonesian free newspapers and independent print media produced by IMDWs in Hong Kong. Furthermore, it has focused on print media intentions, their influence and significant contributions to IMDW activism in Hong Kong.

Research studies on the topic of the IMDWs' lives in Hong Kong has mostly focused on the relationship between migrant workers and law, human rights and inequality, gender, protest and activism, and so on (Lai 2007, Liu 2010, Ignacio \& Mejia 2009). However, no comprehensive research has intensely discussed Indonesian female domestic workers' activities in the form of media activism. Furthermore, scholars tend to examine what has happened to IMDWs abroad. IMDW activism, especially in the production of messages through conventional media and the Internet, has been only briefly discussed (Briones 2009, Killias 2009). IMDW activism is possible in Hong Kong because the country permits protests (within certain limits). Hence, migrant domestic workers have the opportunity to publicly express criticism without fear of "violence or a militaristic police crackdown" like "governments elsewhere" (Constable 2009:155-156). This situation is in contrast to that in other countries that receive foreign workers, such as the Middle Eastern nations where migrant workers are not as well protected by government guidelines.

Previous publication has concerned the Indonesian media in Hong Kong. The Jakarta Post, for example, published an in-depth story about Suara, an Indonesian free newspaper produced and distributed in Hong Kong (Graham 2007). Edith Koesoemawiria's Indonesian diaspora and minority media: mirroring me daily (2008) also discusses the existence of Indonesian print media in Hong Kong. She examines Indonesian newspapers in Hong Kong and compares the situation with what has occurred with Chinese diasporic media in Indonesia. Nevertheless, the positions of IMDWs in media activities have not been discussed in either context. Significantly, the writing has a strong focus on the conditions of IMDWs in Hong Kong in relation to their participation in media activism. Moreover, ethnography was used to help identify and describe the situation of IMDWs in relation to the use of print media for activism purposes.

This study has the potential to reveal how the typically exploitative and difficult conditions for migrant workers in their host countries can be addressed if access to the media is not restricted and the freedom of migrant workers to express issues and concerns is guaranteed by the regulating government. More specifically, the writing discusses the role of Indonesian newspapers and the dynamics of this medium within the IMDW community in Hong Kong. Interactions have been examined between IMDWs and Indonesian newspaper journalists, both in a professional setting and in their daily social lives. Relationships have been elaborated on between journalists and government 
officials (in this case, Indonesian Government representatives in Hong Kong). The research focused on four Indonesian language newspapers in Hong Kong that are free and have both a regular and huge distribution. It is argued that the news published by the Indonesian newspapers has an impact on the experiences of living in Hong Kong for the IMDWs and in some cases, how it has raised tension between IMDWs and the press. Magazines and tabloids published independently by IMDWs have also been examined. To focus the analysis, Indonesian newspapers imported from Indonesia will not be included. Although these are sold and distributed in Indonesian stores across Hong Kong, their content is limited to events in Indonesia and they do not employ journalists based in Hong Kong.

\section{Research Method}

The research applied ethnographic approaches to examine Indonesian print media in Hong Kong as advocacy tools for IMDWs in Hong Kong. The term ethnography may be applied to qualitative research whose aim is to gather an in-depth, specific description of certain cultural and social situations. Clifford Geertz (1973:3) says that ethnography aims to provide a cultural interpretation of a certain condition existing in a society. As described by John Van Maanen (1998:3), ethnography is the "written representation of culture". Fieldwork was conducted in Hong Kong's Special Administrative Region (SAR) in 2013 and 2014. Participant observations, in-depth interviews, and focus group discussions were employed in this research.

For this research, the conventional ethnography definition of Hammersley and Atkinson (1983:2) was followed: "the ethnographer participates, overtly or covertly, in people's daily lives for an extended period of time, watching what happens, listening to what is said, asking questions; in fact collecting whatever data are available to throw light on the issue with which he or she is concerned". Nonetheless, it is realised that undertaking ethnographic research in the context of media studies requires critical understanding. Ethnography in media studies emphasises on the interpretations of media constructed by the audience in their everyday lives, where "it is true they (media studies) are not based on extensive fieldwork in distant lands, but they do share some of the same general intentions as anthropological (ethnographic) research". (Moores 1993:4).

There has been considerable ethnographic research focusing on migrants (Anggraeni 2006, Constable 2007 and 2014, Sim 2002 and 2007). However, there are a limited number of ethnographers working on IMDW issues with a focus on media and cultural studies. Ethnographers are attempting to address Indonesian migrant involvement with media in their research, although they provide no further discussion on the topic. Broader discussions in migration and media have been developed by Alonso \& Oiarzabal (2010) and Madianou \& Miller (2012) with a diverse range of migrants' perspective from around the world. Nevertheless, ethnographic research on media and Indonesian migrants, especially those living in Hong Kong, has not been undertaken to my knowledge.

\section{Result and Discussion}

In 2015, there were 54 daily newspapers and 679 periodicals listed by the Government of Hong Kong (Government of Hong Kong website 2015). This includes four Indonesian newspapers instituted in Hong Kong. In general, these newspapers are bundled in tabloid size, which is around half the size of a broadsheet format. The size suits the profile of a free newspaper.

Free newspapers are one solution to the corporate monopoly of paid newspapers in readership and circulation (Bakker 2008:427). They provide news for readers and space for advertisers. A large readership brings greater advantages to advertisers, because the advertisements are read by more people (Silva \& Resende 2013). In today's print media industry, a free newspaper is an unorthodox way to enable print media to exist amidst uncertainty around the industry's sustainability: "no one can predict the future of the newspaper industry, but it can be said with confidence that free is a model still relevant to print" (Tennant 2014:118).

The existence of Indonesian free newspapers is an interesting discussion topic among IMWs in Hong Kong. However, writing and research on this topic is limited. However, one relevant article was 
written by Koesoemawiria (2008), in which she briefly discusses the existence of Indonesian free newspapers in Hong Kong. She lists nine publications that are issued, but only five of them have a regular publication schedule - Berita Indonesia, Rose Mawar, Apa Kabar, Indo Pos, and Suara - and specifically discusses the last in the list (2008:51-52).

During my fieldwork in 2013, I located four existing newspapers: Suara, Apa Kabar Plus, Koran Indonesia (KINDO), and Berita Indonesia. All Indonesian newspapers in Hong Kong depend on advertising to meet their running costs. Each newspaper allocates around half its pages to advertising. Several newspapers even intentionally operate as the promotional instruments of particular companies. Suara and KINDO, for example, were established as marketing tools for cellular products produced by the companies that manage the publications.

The free newspaper format employed by Indonesian publications in Hong Kong employs simpler criteria for content than paid newspapers: the news coverage is lighter and they "offer less news than paid papers ... published as tabloids or even smaller formats ... (and) the number of journalists employed is smaller and they are less experienced" (Bakker 2008:427). All Indonesian free newspapers in Hong Kong have similar news production hierarchies. They are commonly run by a chief editor and news gathering is frequently performed by journalists. Professional journalists from Indonesia are recruited to fill positions as editors and news reporters.

The newspapers also interact directly with IMDWs in news production. Newspapers such as KINDO, Apakabar Plus and Berita Indonesia employ IMDWs as freelance contributors of stories in each edition. These contributors function to strengthen the news coverage team. IMDWs take on this role in their limited spare time.

Indonesian newspaper news products are well received by IMWs. All Indonesian free newspaper editions are 'sold out'. The newspapers are popular not only because they are free, but because the journalists actively promote their newspapers by getting involved in the social activities of Indonesian migrant communities in Hong Kong. The journalists also have a significant influence over IMDWs by participating in migrant organisation events and developing workshops and courses for IMDWs.

The journalists' perspectives on the events about which they write, and their specific roles in the IMDW community, are essential to the discourse of migrant advocacy. As professionals working for the press, journalists have the power to gather opinions and raise issues through their publications. There are different expectations on these journalists. Government officials such as those from the Indonesian Consulate expect journalists to represent the government's image in a positive manner. Media owners expect journalists to write news that contributes to the raising of revenue through advertising. IMDWs and activists expect journalists to help publicise issues related to migrant advocacy and the struggle to fulfil their rights as workers. I discovered that these various expectations are frequently intertwined and may put journalists in a difficult position. The following sections discuss in detail four commercial print media published in Indonesian.

\section{Suara}

Suara was established in 2006 and published by HK Publications, a company located at North Point, Hong Kong. Besides Suara, this company also publishes the Hong Kong News, which is aimed at Filipino migrants. HK Publications occupies the same floor of a building as Kata, a smartphone producer, and Owtel, a cellular phone distributor. These two business entities are administered from the same office as Suara and are under the one managing company. Suara is issued biweekly and finances its operations through advertising income. Kata and Owtel are two clients that advertise permanently in Suara (Hidayat 2013).

Suara's news production is developed and maintained entirely by Hidayat and Mega. They both have multiple tasks including the layout, photography and editing, as well as writing stories. Previously, Suara was handled by more than two people. When it was first established, Suara was managed by Muhammad Fanani with two journalists working on news gathering: Hidayat and Razak. Fanani 
resigned in 2010 and went back to Indonesia. His resignation was followed by that of Razak, who moved to Apakabar Plus. In 2007, Fanani's activities at Suara attracted the attention of a journalist from the Jakarta Post, Duncan Graham. Graham wrote about Fanani's vision for migrant workers' lives in Hong Kong and his efforts to advocate for migrant workers via the news that he produced:

Fanani is planning to move his paper in new directions while continuing to expose cheating agents and brutal bosses, and push for laws to be upheld. He also has the courage to allow criticism of the Indonesian Consulate in his paper-risky because the bureaucrats could make his life unpleasant, shut down his contacts and bad-mouth his reputation among advertisers. Suara has four competitors in Hong Kong, but it is the only paper that employs professional journalists from Indonesia. It is no bland rag, like so many similar papers that rely on handouts and staying sweet with officials (Graham 2007:10-12).

From Graham's article, it is clear that Suara's mission is to advocate for migrant workers through its news. The editor of Suara, Hidayat said that Suara specialises in news about migrants' lives in Hong Kong, as it "realises the potential of IMDWs who need information not only about their family back home, but also about the neighbourhood they live in right now" (Hidayat 2013). The quality of its professional journalism is also hoped to become a point of distinction for Suara from other newspapers. Suara has 28 pages in 35,000 copies printed fortnightly on Friday afternoon. Based on my observation, around 70 percent of the pages are allocated for advertisement. The advertisements are mostly for cellular phone products and accessories, but they also promote Indonesian grocery stores, financial institutions, work agencies, labour law firms and education/course facilities, among others.

However, the fact that Suara depends on advertising and dedicates only a small proportion of space to news is inconvenient for its reporters. Suara journalist Mega said that the high advertising allocation in Suara is problematic, because there is real news that cannot be published due to limited space (Mega 2013). Nevertheless, Mega realises Suara acts as the marketing medium for the company's inhouse products, Kata and Owtel. Kata targets IMDWs because their population is high and they have high demand for communication facilities. According to Hidayat, IMDWs are an attractive target for cellular phone marketing (Hidayat 2013).

Besides their basic features allowing communication with friends and family back home, cellular phones are becoming a symbol of prestige among IMDWs. Using the latest cellular technology is considered important to them, as recognised by migrant activists and migrant issue researchers (Chib, Wilkin \& Hua 2012, Sukesi \& Liliana 2002, Thomas \& Lim 2010). I briefly discussed the strategic use of cellular phones as media to disseminate messages about migrant advocacy and information about migrant labour laws.

Management has given the Suara journalists freedom in their writing for the newspaper. However, the company's focus on advertising could harm the sustainability of the newspaper because they give no attention to the news content. As Mega explained, the "management does not understand the content as they cannot read Indonesian. You could even write negative stories about the Indonesian Government, and the company would not know" (Mega 2013). Mega's statement suggests that there is no control from the company over the newspaper's editorship and the quality of the news, and furthermore, the professionalism of their journalists. This loose editorial control could create the freedom for journalists to write anything based on their own ideology.

\section{KINDO}

KINDO is an abbreviation of Koran Indonesia (in English, Indonesian newspaper). The paper is published and distributed by Field Profit Limited in Hong Kong. Located in the Fair View Commercial building in Sugar Street, Causeway Bay, this company runs a business near to Victoria Park, the centre of IMDW activities in Hong Kong. KINDO is managed by Agus Zunaidi and is published monthly with 24 pages focusing on news related to Indonesian community issues in Hong Kong. For each edition, KINDO prints 30,000 copies. 
$K I N D O$ is distributed for free through several Indonesian stores and restaurants across Hong Kong. KINDO profits came from advertising. Like Suara, KINDO is supported by a commercial cellular phone distribution company. According to Zunaidi, "the company has cellular phone retail shops across Hong Kong called 'Halo'. They place advertisements in every edition of KINDO" (Zunaidi 2013). Halo advertisements take up more than three pages in each edition of KINDO. The advertisement section also includes advertisements for cellular phone accessories, job agencies, Indonesian retail shops, short courses for IMDW and so on.

Zunaidi occupies the position vacated by Ludovicus Mardiyono in 2012 (Zunaidi 2013). There is a vast difference in how KINDO was managed by Mardiyono and the approach of Zunaidi. For migrant activists, $K I N D O$ under Mardiyono was dedicated to migrant advocacy issues and showed its support through news affiliated with the migrant activism agenda. As described by the chair of ATKI, Ganika Diristiani, "Mister Lud (Mardiyono) supported migrant movements. His news reports supported our causes in migrant advocacy" (Diristiani 2013). In contrast, Zunaidi is considered by migrant activists as a journalist who commercialises his existence and has a personal interest, especially with respect to the religious activities of IMDWs. According to the chair of IMWU, Sringatin, the news focus changed from being migrant advocacy-oriented to religious and melodrama-oriented (Sringatin 2014). The shift in newspaper management did not seem to disturb the business owner. In fact, the allocation of pages to advertising in KINDO has increased since the management change.

In its news gathering activities, Zunaidi does not work alone. KINDO employs five freelance news contributors and all of them are IMDWs. KINDO's hiring of freelance journalists is common among news organisations. Reuters, for example, uses freelance journalists "to supplement its network of staff journalists ... (and) ... to cover stories of a specialist nature when we do not have the necessary expertise among our staff" (Reuters 2008). KINDO's decision to utilise IMDWs as its freelance journalists is understandable because an IMDW freelance journalist may have the expertise to write original stories about their community. However, there is a palpable difference in the practice of Reuters and KINDO in recruiting freelance journalists. Whereas Reuters prefers to hire freelance journalists with a high standard of professionalism (referred to by Reuters as 'stringers'), KINDO tends to choose IMDWs with minimal experience in news reporting (Zunaidi 2013). Apparently quality is not a concern for KINDO because the network is most interested in the inside stories provided by the freelancers.

Although the freelancer role is essential, Zunaidi remains the main figure at KINDO and manages all business that is related to the news content in the paper. He claimed that "here in Hong Kong, I am active and known by IMDWs. They assume that KINDO is Agus and Agus is KINDO" (Zunaidi 2013). $K I N D O$ under Zunaidi's management has an exceptional position in the IMDW community in Hong Kong. As stated by Eni Lestari, KINDO does not empower migrant advocacy and support media activism: "Zunaidi has his personal goals in managing KINDO and we do not expect KINDO to be part of the struggle in advocating migrant rights in Hong Kong" (Lestari 2013). Lestari's statement suggests that it is unfortunate that KINDO is one of the Indonesian print media in Hong Kong to be managed in its own way and to break away from the current media activism movement.

\section{Apakabar Plus}

Apakabar Plus is managed by Yuni Tze and Razak. Yuni Tze manages publication and Razak oversees news gathering. The news is provided by freelance journalists in Indonesia and Hong Kong. Apakabar Plus news content is developed and controlled not only by Razak: Yuni Tze also takes part in the news editing and is active in maintaining Apakabar Plus's Facebook page. Apakabar Plus is managed by the Apakabar Company, whose majority share is owned by Yuni Tze.

Apakabar Plus developed as a free publication published fortnightly and prints 35,000 copies per issue with an area of distribution ranging from Macau and Hong Kong to Indonesia. Apakabar Plus focuses on soft news and features, so the management prefers that the publication is considered a tabloid. As explained by Rogers (2015): "broadsheets are associated with a high-minded approach 
to the dissemination of news with an upscale readership. (While) tabloids tend to be more irreverent and slangy in their writing style". Like other free Indonesian language publications in Hong Kong, Apakabar Plus depends on advertising for its income. Advertisements occupy around 45 per cent of its 36 pages. Interestingly, because Apakabar Plus is independently managed, it is not required to place advertisement materials from a donor company as occurs with Suara and KINDO.

Apakabar Plus offers a different approach to servicing the needs of IMDWs in Hong Kong. The tabloid has Indonesian celebrity news as its headlines and provides updates on celebrity gossip. As critically discussed by Turner, there is a big question mark about whether celebrity articles should be considered news, as it tends to be used as a marketing tool for celebrities to capture the audience's attention (2014:145-146). However, Turner sees that such articles are "probably the key area where we can see consumers unproblematically accepting gossip or rumours as news" (2014:150). Indeed, IMDWs are consumers who can also enjoy celebrity news. The strong interest in the lives of celebrities from the IMDWs' home countries has been captured by Apakabar Plus and handled as a distinct product that is positioned differently in the landscape of Indonesian print media in Hong Kong.

Celebrity news provided by Apakabar Plus provides a choice for IMDWs who do not want to read about politics, economics or other kinds of 'serious' news. Celebrity news may distract the audience's attention from important problems that arise in public discussion, and become a way to escape daily conversations about important matters in society (Couldry, Livingstone \& Markham 2007, Dubied \& Hanitzch 2014). Reading celebrity news may also be used by IMDWs to free themselves from the pressures of their daily routine. Stories about Indonesian celebrities are easily accessed by IMDWs over a web browser on their smartphones or from imported Indonesian magazines sold by Indonesian stores in Hong Kong. However, Apakabar Plus offers more in-depth coverage of problems experienced by public figures. As mentioned by Razak, "I gather news from several sources, and it is not always about artists, musicians or movie star rumours. Scandals involving political figures are also interesting to my readers" (Razak 2013). Apakabar Plus makes celebrity news its central attraction, and every section provides entertaining content.

Apakabar Plus has 15 sections. According to Razak, some of the sections are particularly well liked by the readers: "Sections such as fashion, horoscope, Kampung halaman (hometown) and Jepret (click) are popular among our readers". The Kampung halaman section, for example, provides a space for Indonesian families trying to locate their daughters and wives working as IMDWs in Hong Kong. Stories in this section generally describe a wife/daughter/mother that abandoned her family back home and disregarded them by sending no news about her wellbeing in Hong Kong. Razak explained that "Family members tell their stories to our contributor in Indonesia. We pack the stories into a narrative feature. This section tries to help families reconnect with their loved ones by publicising their story and photographs of the lost IMDW and her family" (Razak 2013). However, criticism has been raised because it does not provide updates on whether a 'lost' IMDW mentioned in the section had been found. It is evident that the section was only created to share sad stories and ask for the readers' sympathy.

Sections in Apakabar Plus have attracted criticism from an IMDW, Susi Utomo. She observed that Apakabar Plus exploits IMDWs:

Apakabar Plus provides a page that contains photos from readers of their fashion creations. From the perspective of creativity the page is good, but this has created competition among migrants who spend a lot of money buying materials for their designs to have them published in the tabloid. Yet they are supposed to send the money they earn to their family at home (Utomo 2014).

Utomo also identified problems with Apakabar Plus in them providing space for young IMDWs to have their photographs published. IMDWs' youthfulness is associated with a need for affirmation, and the media is responsible for an unprecedented amount of content published on this matter (Papadopoulos 2010:7). For young IMDWs, with their limited experience in contextualising what they are seeing, the only thing that matters is to be attractive and to appear in the media, as facilitated by Apakabar Plus. 
Facilitation of young female IMDWs' expression through publication of their photos in Apakabar Plus may encourage IMDWs to give more attention to their physical appearance. By inviting IMDWs to send their photos, Apakabar Plus has indirectly set the standard for body image as perceived by the readers. Further, through the Kampung halaman section, the tabloid has conserved the traditional stereotype of a woman that needs to be submissive to their family/husband even though they are working abroad. In addition to criticism about various sections in Apakabar Plus, the tabloid has also been examined over its treatment of its freelance journalists. Like KINDO, Apakabar Plus employs freelance contributors to cover news. One such contributor in Hong Kong is Hanna Yohana, an IMDW who has worked for the publication since 2012. She performs her journalism activities during her days off on Sundays, and contributes four or five articles per edition. Regarding Yohana's contributions in Apakabar Plus, Eni Lestari, migrant activist and a friend of Yohana's, said that Yohana's role was to provide the inside story on how IMDWs are struggling to achieve their rights in Hong Kong. However, according to Lestari, Yohana's role is insignificant and she is given only limited space in the publication (Lestari 2015). Lestari explained:

Hana Yohana frequently grumbles about her contribution to Apakabar Plus. Her stories are neglected by the editor. Yohana thinks that the editor does not like her, because she is active in organisations and participates in protests against agencies and the Indonesian Consulate. Her editor, Yuni Tze, had issues with migrant activists in the Erwiana case. Tze was the first person to publicise Erwiana's condition, on Facebook in early 2014. Tze and her friends then contacted Erwiana offering assistance, but Erwiana chose JBMI to guide her case. Since then, Tze has become cynical about organisation activities. From what I can see, conflict of interest became an important factor in the news editing process.

Despite its sections that encourage female stereotyping and issues among migrant activists, Apakabar Plus has managed its role within the Indonesian migrant community for several years. Its positioning as a tabloid covering soft news distinguishes it from similar publications in Hong Kong.

\section{Berita Indonesia}

The other notable free Indonesian print publication in Hong Kong is Berita Indonesia, which was established by Berita Indonesia Limited, a company led by an Indonesian entrepreneur, Sam Jauhari. The Indonesian community, especially migrant workers, tend to associated Berita Indonesia with Rio Chan, the newspaper's editor in chief. Chan emphasises that as a supplement "Peduli provides inspiration about businesses in Indonesia so that returning IMDWs can picture what business they might become involved in once they are back home. IMDWs are very consumptive. Their drive to shop is high, but now there is a trend for IMDWs to invest their money in entrepreneurial activities" (Chan 2013).

Chan is an entrepreneur enthusiast. During our interview, he admitted that his news products endorse entrepreneurship among migrant workers. He has personal reasons for this. According to Chan, five years ago, IMDWs in Hong Kong "matched the stereotype of stupid and tacky, and the Indonesian media exposed these stereotypes by publishing negative stories about IMDWs". Chan admitted that he was one of the journalists that also sold the tragic stories of IMDWs in Hong Kong:

By that time, I happened to be a Hong Kong-based news contributor for several media in Indonesia. There was one migrant worker who committed suicide by jumping from a high-rise apartment. I wrote the story and the tragedy was a headline for two days in a row in Indonesia. Indonesian migrant tragedies are transformed into interesting news in Indonesia. Positive news such as an IMDW's success in developing her business, for example, does not make headlines. That is why I now only publish positive, empowering and inspiring news through the newspaper that I work in. I have an obligation to guard the image of Indonesian migrants in Hong Kong.

Chan said that he has sympathy for migrant workers living in Hong Kong. To express his sympathy, Chan tried to build a clear vision for his publication. Berita Indonesia delivers the concept of 'inspiring news', where readers can find supportive stories and information regarding their existence as migrants in a foreign land: "This was because Indonesian migrants are struggling every day for 
their life, yet they need to access information that can relieve them and raise their spirit" (Chan 2013). Chan claims that all news published by his tabloid is to inspire the readers: "I told my news contributors that inspiration is the main idea, so it has appeared in every publication" (Chan 2013).

Berita Indonesia's headlines are predominantly about Indonesian migrant events and related issues in Hong Kong. In one edition, Chan placed a headline about an entrepreneurial event for Indonesians in Hong Kong. He believes that entrepreneurship is the key to IMDW's success because it is "about giving inspiration to the migrant society. I know it since I also perform entrepreneurship. I perform a small business in importing women's clothing from Indonesia" (Chan 2013). Berita Indonesia publishes 24 pages of information, mostly on the existence of Indonesian workers in Hong Kong. Soft news, entertainment and gossip is the main content, and are packaged in simple writing. Regarding this, Chan said that the newspaper had to "deliver news in a moderate and understandable style. It does not mean that we are underestimating readers. We just need to communicate with the daily language that they understand" (Chan 2013).

Chan admits that through the stories published in Berita Indonesia, he is on a personal mission to empower fellow Indonesians working in Hong Kong as migrant workers. His individual action as a journalist controlling the layout and content of the publication has given him significant power to direct issues as he desires. During the interview, Chan claimed that he has the freedom to direct the content every month because the company for which he works trusts him (Chan 2013). As a consequence, the content of Berita Indonesia solely represents Rio Chan's point of view.

Berita Indonesia is known as a tabloid that is far from controversial and that provides 'safe' information regarding migrant life in Hong Kong. Unlike Suara, Apakabar Plus or KINDO, Berita Indonesia tries to satisfy everyone with the content that it publishes. Chan's close connections with migrant organisations, the Indonesian Consulate and several Indonesian institutions in Hong Kong have given him the opportunity to broaden his networks, in sourcing information. On the other hand, what Berita Indonesia offers via its news product has given a strong sense that Indonesian publications in Hong Kong may have complete editorial control, without government or corporate influence.

\section{Migrant-made print media}

The establishment of Indonesian free newspapers in Hong Kong has promoted dynamic developments in the IMDW community in Hong Kong. The existence of newspapers helps the IMDW community to stay abreast of recent news and information about their community and livelihood in Hong Kong. Newspaper journalists also actively contribute to migrant activities and are influential in the capacity building of IMDWs. Nevertheless, conflicts between several journalists and migrant organisations have damaged the free newspapers' credibility. Distrust declared by migrant activists about several Indonesian free newspapers in Hong Kong has been a major driver of IMDWs publishing their own version of print media.

However, not all print media published independently by IMDWs are the result of disappointment with the existing Indonesian newspapers in Hong Kong. Several publications are produced mainly because IMDWs want to channel their creativities in writing. This has resulted in a range of publications with diverse discussion angles being distributed among IMDWs. This section examines the known independent print media managed and produced primarily by female IMDWs in Hong Kong, which consists of two newspapers, Vokal (vocal) and Sinar Migran (migrant light), and four magazines, BHSI, CahayaQu, Iqro and Nurmuslimah. These print media are produced independently by IMDWs and distributed for the consumption of their colleagues.

Vokal is produced by ATKI. Even though its publication schedule is not regular, ATKI is trying to provide an alternative to migrant workers regarding news content and information. Vokal is printed in a tabloid format with news and stories focusing on issues and discourses of migrant advocacy and protection. According to Ganika Diristiani, chief editor of Vokal, the publication is an effort by ATKI to respond to IMDWs' disappointment in current Indonesian newspapers in Hong Kong: 
We feel that the Indonesian newspapers in Hong Kong are exploitative and give much false information about the existence of migrants. They only care about advertising and using migrant workers as an object of marketing. Their news frequently contradicts our positions and they have no intention of promoting law literacy among migrants (Diristiani 2013).

Diristiani realises that Vokal as an alternative media is far from perfect because it is created by members of ATKI, who work full time in households and have no proper knowledge about professional publications. However, they are trying hard to make their own ideal version of a newspaper:

We work as a team in Vokal where some work as journalists, some take care of writing materials, and some work on tabloid layout. We are trying to share information and news about migrant workers' needs, and solutions to their problems in understanding migrant laws, and their employment issues (Diristiani 2013).

The title Vokal was chosen by the publisher to emphasise that readers should be brave in vocalising their concerns, especially regarding their condition as migrant workers in Hong Kong (Diristiani 2013). Each edition of Vokal is printed in 1,000 copies and distributed among ATKI members and its affiliates (Maysaroh 2015). Vokal is not distributed for free, but the producer does not set a particular price for each copy. Maysaroh said that Vokal is distributed on a voluntary basis and that it is an important instrument for organisations, because it "provides balance to information from Indonesian newspapers in Hong Kong, and importantly, it is being used by organisations as a tool for education, information sharing and propaganda" (Maysaroh 2015).

Propaganda, as mentioned by Maysaroh is key to the publication. According to the Blackwell dictionary of modern social thought (2006:529-530), the word "propaganda" refers to "the deliberate attempt by the few to influence the attitudes and behaviour of the many by the manipulation of symbolic communication". Propaganda as explained by Maysaroh is considered more as a mission performed by Vokal in an effort to provide relevant information and new perspectives on IMDWs' lives in Hong Kong. Furthermore, Maysaroh explained:

\footnotetext{
Propaganda may be understood as a negative action involving information falsification. But propaganda in our perception is encouraging migrant workers to understand their true condition and giving appropriate guidance on how to cope with the situation. This propaganda is reflected in Vokal's content, where you can find many articles intending to open migrant workers' minds about their rights and how to deal effectively with employment laws in Hong Kong and Indonesia. You cannot find this information in mainstream Indonesian publications in Hong Kong.
}

Vokal is published as 16 pages divided into nine sections: editorial, current issues, Hong Kong news, regional news, opinion, a migrant worker's diary, variety and readers' letters. Vokal has an editorial as its main content. In the April 2013 edition, for example, an editorial titled Migrant workers' placement and protection Law No. 39/2004 revision draft: to protect migrants or agencies? was placed on the cover page and continued to pages 2 and 3. The editorial section consists of Vokal's point of view on certain problems where "ATKI's position is reflected in the editorial" (Diristiani 2013).

The current issues section contains news about ATKI activities and other affiliate organisations' events that happened in the previous three months. The Hong Kong and regional news sections delivers news about recent discourse in the migrant workers' lives. In the July 2013 edition, the rise of fuel prices in Indonesia became a topic on which migrant organisations expressed their opinion to the Indonesian Government through a street protest in front of the Indonesian Consulate in Hong Kong. The opinion section facilitates IMDWs in sharing their thoughts on certain issues. In the July 2013 edition, Cieciet Bunciet Antique, a member of one Indonesian migrant organisation wrote a response to an Indonesian Consulate officer statement in the Suara newspaper. She defended her fellow organisation member who was verbally attacked by the consulate officer. This counter opinion is considered important in providing a written alternative point of view for the readers. The opinion section highlights Vokal's position as alternative media, whose role differs from that of commercial Indonesian print media in Hong Kong. 
Vokal was created in an ideal manoeuvre to match, or at least give balance, to the influence of commercial Indonesian print media in Hong Kong. Despite the positive factors emerging in the publication of Vokal, criticisms have arisen regarding the tabloid. According to Maysaroh, several readers have complained about the serious issues raised in the tabloid: "readers have difficulty digesting the content of the tabloid. They feel that the language style is too exclusive and the articles are too long" (Maysaroh 2015). The placement of an editorial on the cover page could also be problematic because of there being too much writing. This may cause the readers to hesitate to read the tabloid. Vokal may have problems in translating its mission to provide alternative reading for IMWs in Hong Kong. Newsroom members' lack of experience in journalism and media management may become obstacles to the creation of a quality publication. However, the spirit of migrant workers in managing Vokal and their durability in keeping production going are the main features of its success.

Like Vokal, Sinar Migran was also developed as a solution to IMDWs' need to receive balanced news and information relating to their existence in Hong Kong. When materials delivered by Indonesian free newspapers are considered insufficient and misleading, Sinar Migran fills the gap by delivering news products that are more straightforward. First released to the public in December 2015, Sinar Migran is packaged in tabloid format and distributed not only in Hong Kong, but also in Macau, Taiwan and Indonesia. Sinar Migran is produced by JBMI and distributed by the organisation members. It is printed over 16 pages and produces 2,000 copies per edition. Sinar Migran sells for HKD5 per copy.

As vocal as Vokal, Sinar Migran in its first edition immediately criticised policies by the Government of Hong Kong regarding domestic workers' working hours and assisted contracts run by migrant agencies. In its editorial, Sinar Migran wrote that domestic worker working hours must be regulated and determined fairly, as with other work. Regarding the overcharging experienced by IMDWs, Sinar Migran has encouraged the Government of Hong Kong to legalise independent working contracts without interference from migrant agencies. Overcharging happens because migrant agencies charge an excessive amount of money to IMDWs as a fee for the work placement.

Vokal and Sinar Migran are not the only alternative print media dedicated to migrant workers. Using magazine form, several groups of migrant workers are publishing their creations in diverse areas of interest. The content of magazine products from migrant workers is usually thematic. One such publication is $B H S I$, an Indonesian magazine published in Hong Kong with an entrepreneurial and investment approach. The magazine supplies information enabling the migrant workers to invest their money in different business entities while they are still working in Hong Kong. This magazine is published by BHSI, a group of IMDWs active in creating events and workshops on investment and entrepreneurship.

Other magazine publications attract readers through their religious and spiritual content. I noted three such Indonesian language publications distributed in Hong Kong: CahayaQu, Nurmuslimah and Iqro. Megawati, former Editor in Chief of Nurmuslimah magazine said that religious magazines have significant potential in the Indonesian migrant media market in Hong Kong (Megawati 2013). Unlike Indonesian newspapers in Hong Kong that are distributed for free, readers pay $\sim$ HKD10 for each edition, published once per month (Megawati 2013).

Susi Utomo, Editor in Chief of CahayaQu magazine pointed out that migrant workers are busy every day, "but as humans, we also need spiritual motivation and updates on our religious beliefs" (Utomo 2013). Utomo claimed that these needs are at least facilitated by the Indonesian free newspapers in Hong Kong: "that is why we make our own publication, to support our fellow migrants' spiritual needs and supporting them to remember their creator" (Utomo 2013). CahayaQu was established in 2012 by Muslim IMDWs and is published bimonthly, distributed both in Hong Kong and Indonesia.

Megawati considers that these magazines have a different motivation, other than just spiritual. She says it is more about community and subjectivity, and that religious magazines facilitate her religious thoughts through writing: "Nurmuslimah's vision suits me in promoting the identity of Muslim women as knowledgeable, and not katrok (simple-minded). Importantly, Nurmuslimah was 
developed purely by IMDWs and no outsiders can interfere". Nurmuslimah was established in 2011, printed in 3,000 copies and distributed in Hong Kong and Macau (Megawati 2013).

Iqro is another religious magazine, and is managed and published by Dompet Duafa (an Indonesian organisation in the charity business). Dompet Duafa has an office in Hong Kong that frequently manages religious events and collects donations from migrant workers. Iqro was established in 2009 and is the first religious magazine to be published not only in Hong Kong but also in Taiwan (Megawati 2013). Megawati explained that Iqro is well maintained and has a stable management because it is supported by an established organisation:

Independent magazines such as Nurmuslimah find it difficult to survive because their funding is not stable. Their production is funded by migrant workers who frequently have financial problems. We aim to attract a higher revenue from advertising because depending on income from sales is not a long-term solution.

Different publications face different issues. Utomo admitted that the CahayaQu team is able to sell the magazine effortlessly. Utomo said that 5,000 copies of CahayaQu are printed per edition, "and it is nearly sold out one week later just in the Hong Kong market". CahayaQu has published nine editions since 2012. According to Utomo, CahayaQu is the result of her restlessness in dealing with the lives of migrant workers in Hong Kong:

The idea to publish CahayaQu came from my contemplation while I was still working at Apakabar Plus tabloid. I investigated many migrant problems. Of 150,000 Indonesian migrants in Hong Kong, at least 5 per cent have experienced serious problems. I wanted to help them. So basically IMDWs came here for a reason and most were dealing with problems back home. They came to Hong Kong to run away from their problems. Yet they arrived here without mental preparation. They felt like they found heaven in Hong Kong. They were not prepared for long-term planning. Most Indonesians are Muslims, but their attitudes are far from Islamic values. Most magazines in Indonesia concentrate on politics and entertainment. We need basic guidance, particularly sourced from the holy book. We need to deliver the message with understandable language, and from the heart. With the media, I intended to help by providing spiritual incentives and bringing us as migrant workers closer to God. It will not be enough to join an organisation to solve your problem. You need God (Utomo 2013).

Utomo's mission is to disseminate religious messages through the media and to communicate with her colleagues living in Indonesia: "I was helped by my friend, Kang Romel who is a journalist from Indonesia to discuss the magazine contents. Here I worked with two of my friends collecting news" (Utomo 2013). Utomo explains how the publishing routine of the CahayaQu crew is not too complicated. They need 15 days to collect materials for articles and on the 20th day, they begin to edit and choose the scripts before doing the layout (Utomo 2013). The CahayaQu crew uses virtual channels to deal with the process of publication:

We discuss monthly themes through Facebook messenger to be more time efficient and minimise geographical gaps. So in practice we have a virtual office and we can access the office via cell phones. I also do not have to go to the printing company because I just send magazine materials to them via email. The printed copies of the magazine are sent to Hong Kong via mail. I also tend to do discussion scripts or interviews via email. Because of this type of communication, my sources can prepare and have time to answer my questions (Utomo 2013).

The editorial crew works to fill 58 pages in the magazine and most of the content of the articles is written by clerics in Indonesia. One column is reserved for a famous Indonesian cleric, Yusuf Mansur, who writes on different topics in each edition of CahayaQu. Yusuf Mansur is frequently invited to give lectures in Hong Kong and according to Utomo has maintained a strong relationship with her group. As the leader of the magazine, Utomo said that she needs to have good relationships with other elements of Indonesian society in Hong Kong, including Muslim organisations and the Indonesian Consulate. Utomo and her team's efforts to discuss religious and daily life issues in CahayaQu have succeeded in attracting readers' attention. Feedback from readers is also positive 
and is expressed through text messages visits to the office (Utomo 2013). Utomo said "I experience goose bumps every time I read messages from readers expressing their joy and emotion after reading CahayaQu". Readers are enthusiastic about CahayaQu because it provides them with what they cannot access from other Indonesian print media:

Simple topics in religious issues make Indonesian migrant workers interested. But when it comes to complicated issues they are not interested. I assume that the language and the delivery style are important for their comfort. I have the same work as my readers. So I try to make quality news suit migrant workers' understanding. Straightforward news is not our style. We wrap the news into a feature style (Utomo 2013).

The success of CahayaQu magazine prompted Utomo to widen her activities in other areas. She established a traditional medication course through the Thibun Nabawy Institute. This institute runs courses at several locations in Hong Kong. Utomo explained that the courses are intended to give migrant workers additional skills when it comes to practising traditional medication: "the institute teaches course participants to practise modes of medication practised in the time of Prophet Muhammad. They can practice it for themselves or for other people. The skills can also be used as a source of income" (Utomo 2013). The Thibun Nabawi institute manages a wide range of courses in Wan Chai mosque and also in Chai Wan. Utomo explained how the courses are programmed to run over several continuous meetings. Each course has its own price, and the institute does not have to worry about promoting its business because CahayaQu magazine is always ready to publish the advertisement.

For Utomo, the magazine has become a strategic tool for marketing. A migrant worker developing a business by using the media to create income outside of their core job in the domestic sector shows notable initiative. However, these actions are not so different from Indonesian commercial print media's commercial endorsements. The only difference is that Indonesian free newspapers are selling advertising whereas the magazines are selling religion.

As explained by Nuraini, religious magazines have the same emphasis on commercialism, but with a different approach: "Indonesian free newspapers are business-centred by placing a lot of advertisements on their pages, whereas religious magazines sell activities with financial contributions and souvenirs such as clothing and books. They actually have the same business orientation" (Nuraini 2013). Nuraini's point in commenting on the existence of Indonesian print media in Hong Kong is significant in the discussion of media roles in the life of migrant workers in Hong Kong. IMDWs are targets for Indonesian print media in Hong Kong, selling materials advertised or activities promoted. The final goal of this media is not far from profit making and IMDWs are clearly the final consumers who are hit hard by this commercialism.

\section{Conclusion}

The Indonesian free newspapers in Hong Kong are managed by journalists who have wide networks and a diverse range of relationships within the Indonesian community. The four newspapers discussed have editorial figures that control the news content based on their professional and personal ideologies, which prompts both admiration and criticism from their target readers: IMDWs. Print media published by IMDWs aim to solve the problems caused by the Indonesian free newspapers. IMDW media such as Vokal and Sinar Migran have published news that directly criticised policy regulators: the Government of Hong Kong and the Indonesian Consulate in Hong Kong - two institutions that would never be challenged by Indonesian free newspapers. Magazines produced by IMDWs have also become a balanced source of information giving IMDWs options for enjoying a different type of news provided for them in the host land. Nevertheless, the business factor has seemingly become a main concern in the existence of Indonesian print media in Hong Kong. Although newspapers sell advertising, magazines sell activities that need contributions from IMDWs, which brings them into the realm of consumerism.

Despite pros and cons regarding the existence of Indonesian print media in Hong Kong, they have undeniably contributed to the capacity development of IMDWs in Hong Kong. Print media have 
published a variety of news useful for IMDWs, fulfilling their need not only for information, but also for entertainment. Different positions taken by the newspapers provide choices for IMDWs in accessing relevant information for their needs. The activities performed by journalists have also enriched the IMDWs' experience and access to the knowledge that they need outside of their isolated workplaces. The Indonesian print media provides access for IMDWs to news about their surroundings. The newspapers and magazines function not only as a bridge of information to what is happening in Hong Kong, but they also continually inform the IMDW community. This provides genuine evidence of how a diasporic community can communicate through various channels and utilise those channels to strengthen bonds among the migrants.

\section{References}

Anggraeni D (2006) Dreamseekers: Indonesian Women as Domestic Workers in Asia. Jakarta: Equinox.

Atkinson P \& Hammersley M (1994) Ethnography and Participation Observation. In: NK Denzin \& YS Lincoln (eds). Handbook of Qualitative Research (248-261). California, CA: Sage.

Bakker P (2008) The simultaneous rise and fall of free and paid newspapers in Europe. Journalism Practice, 3:427-443. http://dx.doi.org/10.1080/17512780802281164.

Briones L (2009) Empowering Migrant Women: Why Agency and Rights are Not Enough. Farnham, England: Ashgate.

Constable N (1997) Maid to Order in Hong Kong: Stories of Filipina Workers. Ithaca, NY: Cornell University Press.

Constable N (2007) Maid to Order in Hong Kong: Stories of Migrant Workers. Ithaca, NY: Cornell University Press.

Constable N (2009) Migrant workers and the many states of protest in Hong Kong. Critical Asian Studies, 41 (1):143-164. http://dx.doi.org/10.1080/14672710802631202.

Constable N (2014) Born Out of Place: Migrant Mothers and the Politics of International Labor. London, England: University of California Press, Ltd.

Couldry N, Livingstone S, \& Markham T (2007) Media Consumption and Public Engagement: Beyond the Presumption of Attention. New York, NY: Palgrave McMillan.

Chib A, Wilkin HA, \& Hua SRM (2013) International migrant workers' use of mobile phones to seek social support in Singapore. Information Technologies \& International Development, 9 (4):19-34. http://itidjournal.org/index.php/itid/article/view/1122/452.

Diristiani G (2013) [Personal communication] 2 July.

Diristiani G (2013) [Personal communication] 6 June.

Dubied A \& Hanitzsch T (2014) Studying celebrity news. Journalism, 15 (2):137-143. http://dx.doi. org/ 10.1177/1464884913488717.

Geertz C (1973) The Interpretation of Cultures. New York, NY: Basic Books.

Graham D (2007) Mohammed Fanani: Publish and be profitable. The Jakarta Post. http://www. thejakartapost.com/news/2007/09/20/mohammed-fanani-publish-and-be-profitable.html.

Hidayat B (2013) [Personal communication] 5 June.

Hidayat B (2013) [Personal communication] 6 June.

Ignacio E \& Mejia Y (2009) Managing labour migration: The case of Filipino and Indonesian domestic helper market in Hong Kong. International Labour Organization. http://www.ilo. org/wcmsp5/groups/public/---asia/---ro-bangkok/documents/publication/wcms_101824. pdf.

Killias O (2009) The politics of bondage in recruitment, training and placement of Indonesian Migrant Domestic Workers. Sociologus, 2:145-172. http://dx.doi.org/10.3790/soc.59.2.145. 
Koesoemawiria E (2008) Indonesian diaspora and minority media: Mirroring me daily. Proceedings of the fourth Symposium forum Media and Development (50-56). Bonn, Germany: Protestant Academy of the Rhineland. Retrieved from http://fome.info/wp-content/uploads/2014/06/ FoME-Media-On-The-Move-2008.pdf Hong Kong Basic Law. (n.d.). The Basic Law of the Hong Kong Special Administrative Region of the People's Republic of China. http://www. basiclaw.gov.hk/en/basiclawtext/images/basiclaw_full_text_en.pdf.

Lai M (2007) Field note: In your face: Indonesian domestic workers' activism at the world trade organization ministerial in Hong Kong. Women's Studies Quarterly, 35 (34):123-127. http:// www.jstor.org/stable/27649699.

Lestari E (2013) [Personal communication] 30 June.

Lestari E (2015) [Personal communication] 19 January.

Liu D (2010) Ethnic Community Media and Social Change: A Case Study in the United States. In: K Howley (ed). Understanding community media. New York, NY: Sage.

Maanen JV (1998) Qualitative Studies of Organizations. New York, NY: Sage.

Madianou M \& Miller D (2012) Migration and New Media: Transnational Families and Polymedia. London, England: Routledge.

Maysaroh (2015) [Personal communication] 2 March.

Mega V (2013) [Personal communication] 16 June.

Megawati D (2013) [Personal communication] 20 June.

Megawati D (2013) [Personal communication] 10 June.

Moores S (1993) Interpreting Audiences: The Ethnography of Media Consumption. London: SAGE Nuraini (2013) [Personal communication] 13 June.

Oiarzabal P (2010) Basque Diaspora Digital Nationalism. In: A Alonso \& PA Oiarzabal (eds). Diasporas in the New Media Age: Identity, Politics, and Community. Nevada, NV: University of Nevada Press.

Razak A (2013) [Personal communication] 6 June.

Papadopoulos L (2010) Sexualisation of young people. London, England: Crown. http://webarchive. nationalarchives.gov.uk/+http:/www.homeoffice.gov.uk/documents/sexualisation-ofyoung-people.pdf.

Reuters (2008) Dealing with stringers. Reuters Handbook of Journalism. http://handbook.reuters. com/?title=Dealing_with_stringers.

Silva JC \& Resende J (2013) Free daily newspapers: Too strong Incentives to Print? Portuguese Economic Journal, 12 (2):113-130. http://dx.doi.org/10.1007/s10258-013-0090-2.

Sim A (2002) Organising discontent: NGOs for Southeast Asia Migrant Workers in Hong Kong. Asian Journal of Science, 31 (3):478-510. http://dx.doi.org/10.1163/156853103322895351.

Sim AS (2007) Women in Transition: Indonesian Domestic Workers in Hong Kong. Doctoral Thesis. http://hdl.handle.net/10722/52677.

Sringatin (2014) [Personal communication] 19 April.

Sukesi K \& Liliana D (2012) Empowerment of female Indonesian migrant workers through the utilization of information and communication technology in East Java. International Journal of Social Science Tomorrow, 1 (10):1-6.

Tennant JI (2014) Free newspapers in the United States: Alive and kicking. International Journal on Media Management, 16 (3-4):105-121. http://dx.doi.org/10.1080/14241277.2014.974244.

Thomas M \& Lim SS (2010) On maids, mobile phones, and social capital - ICT use by female migrant workers in Singapore and its policy Implications. In: J Katz (ed). Mobile Communication and Social Policy (175-190). New Jersey, NJ: Transaction.

Turner G (2014) Understanding Celebrity. London, England: Sage.

Utomo S (2014) [Personal communication] 10 June.

Zunaidi A (2013) [Personal communication] 24 June. 